JASEM ISSN 1119-8362

All riahts reserved
Full-text Available Online at www.ajol.info and www.bioline.org.br/ja

\title{
Climate change, sea level rise and coastal inundation along part of Nigeria Barrier Lagoon Coast
}

\section{*1SHAKIRUDEEN ODUNUGA; GBOLAHAN BADRU; OLALEKAN MUMIN BELLO}

\author{
${ }^{I}$ Department of Geography, University of Lagos, Nigeria \\ ${ }^{2}$ Department of Geography, Umaru MusaYar'Adua University, Katsina, Nigeria
}

KEYWORDS: Climate Change, Economic Development, Scenario Analysis

\begin{abstract}
The phenomenon of ocean surges and other morphological processes along the Lagos coastline have generated serious public concern on the vulnerability of infrastructures and coastal services along the entire stretch of the Barrier-Lagoon coastline of Lagos State. This study examines Badagry coastal environment inundations that arise from sea level rise. The study uses an iterative GIS-based simulation that mapped area inundated based on Intergovernmental Panel on Climate Change - Special Report on Emissions Scenarios (IPCC -SRES) classification (A1, A1T, B2, A1B and A2) and Locally Oriented Economic Development Scenarios (LOEDS). The results of IPCC-SRES scenario analysis show that area inundated at the high emission and worse case sea level rise is less than $0.13 \%$ of the study area while the LOEDS inundation area starts having significant impacts as from 4 meter rise in sea level. Since it is only environmental catastrophism and anthropogenic activities that can attain such serious dimension at local, regional and global scales in sea level, it is recommended that coastal protection infrastructures should be integrated in any major developmental activities. () JASEM
\end{abstract}

\section{http://dx.doi.org/10.4314/jasem.v18i1.6}

Climate change has come to be one of the pressing challenges facing our planet Earth in this century as it is increasingly threatening the continuous existence of life on earth. With shifting seasons, climbing temperatures and rising sea levels (IPCC, 2007). Although all countries of the world are susceptible, some have been noted to be more vulnerable than the others. (Nicholls et al. 2007). The coastal areas have been identified to be highly susceptible especially to sea level rise (UN, 2004).The presence of extensive coastal stretches with high concentration of population (Pelling and Blackburn, 2013) especially in Africa has further worsened the situation in the continent as they are often unprepared and usually overwhelmed by the magnitude of climate change impacts (Adebayo, 1998; Odjugo and Ikhuoria, 2003; NEST, 2003; Chindu and Nyelong, 2005; Odjugo, 2005; Adefolalu et al., 2007; Ikhile, 2007).

The coastal areas in Nigeria are endowed with numerous natural and human resources ranging from rich biodiversity mangrove ecosystems of the Niger Delta to the barrier lagoon Coast of the south western Nigeria. The vulnerability of the Nigerian coastline to sea level rise is particularly exacerbated *Corresponding author Email: odushak@ gmail.com by its low lying, densely populated nature and the high concentration of GDP generating industries and infrastructures especially along the barrier lagoon Coast of Lagos-Badagry-Seme border of the southwestern part of Nigeria. From the Nigeria-Benin border to the beginning of the Mahin mud coastline the entire Barrier Lagoon coastal complex of the south western Nigeria is under threat of sea level rise. The situation is more worrisome considering the level of existing infrastructures, ongoing developmental infrastructures and proposed developmental activities within the complex. The Badagry end of the complex is witnessing rapid changes in infrastructural developments and a category A port complex is also being proposed in the area. Considering the current morphological processes resulting from both natural and anthropogenic factors, coastal gradation resulting from degradation and aggradation processes of erosion and weathering of the materials have continually reshaped the coastal lagoon barrier systems including the biodiversity. The extent, rate and nature of the morphological changes is expected to accelerate as it has been noted that the 
anticipated impact of climate change on the coastal zone would lead to; an accelerated rise in sea level of up to 0.6 meters or more by 2100 (Nicholls et al. 2007).

However, an examination of the cumulative effects of the ongoing and proposed developments in relation to the issue of climate change is imperative as a response to the recent infrastructural development and expansion being carried out along the NigeriaBenin border of the Barrier - Lagoon coastline stretch, especially the extensive construction of the

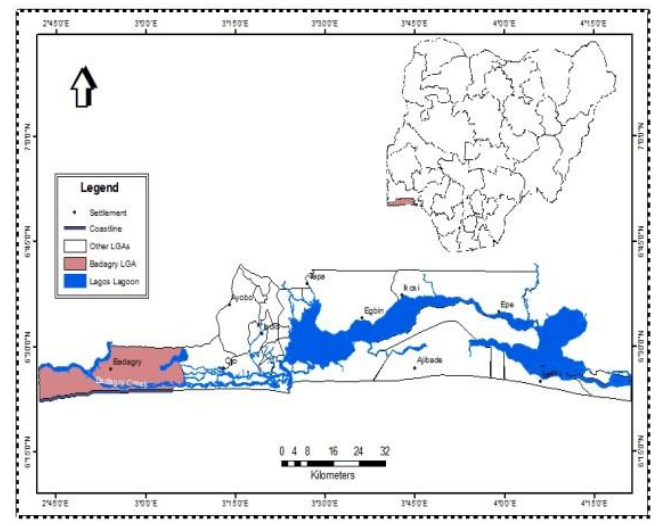

Fig 1: Badagry Coast in Lagos State (Insert: Lagos State in Nigeria)

\section{MATERIALS AND METHODS}

This study adopts the GIS-based inundation model to produce both land use and inundation maps for several emission and sea level rise based on IPCCSRESS and LOEDS. This methodology has been adopted in earlier studies by Nicholls et al (2008), Marfai and King (2008) and Ward et al (2011). Fig 3 shows the flow chat for the study procedure. The spatial data itemized below form the basis for construction of the GIS-models inundation scenarios. The sources and other characteristics of the data are shown in table 1.

The DEM of the study area was downloaded from www.cgiar-csi.org/.../45-srtm-90m-digital-elevationdatabase, an open data source link. The acquired DEM was updated using spot height data obtained from 1:25,000 topographic sheet in ILWIS GIS 3.3 environment. This becomes necessary due to the fact that several parts near the coastline are undersampled For the construction of the inundation road-rail transport system, the proposed Badagry Seaport by the Lagos State Government and other developmental activities along the corridor. Thus, this study investigates the impacts of Badagry coastline (Figure 1) to coastal inundation using Intergovernmental Panel on Climate Change Special Report on Emissions Scenarios (IPCCSRES) classification (A1, A1T, B2, A1B and A2) (IPCC-SRES, 2000 and IPCC, 2007) and Locally Oriented Economic Development Scenarios (LOEDS). Figure 1 shows Badagry Coast in Lagos State while figure 2 shows the specific project area.

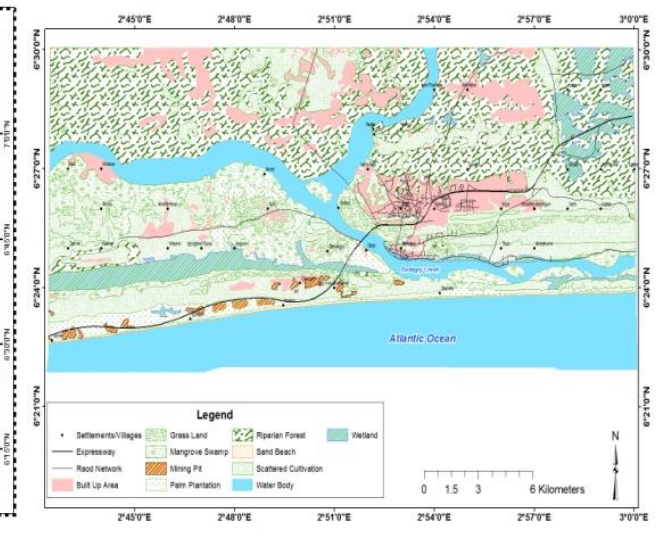

Fig 2: Land Use/Land Cover Map of the Study Area

model, the neighbourhood function of ILWIS was used. This function works iteratively in such a way that successive repetition of a mathematical operation is done using the result of one calculation as input for the next. The calculation stops when the difference of the output compared to the input is negligible, or if the number of iterations as defined is reached. In this case, several iteration processes based on either IPCC-SRES or LOEDS were made (table 3).The predicted high and low sea level rise (0.18 and 0.59 meters) as given by IPCC-SRES was used as inputs to assess land area that would be inundated if such an event occurs. The input map for iteration is called a start map and contains pixels, which act as the starting point of the calculation. The iteration expression defines a certain condition (based on dual height as in elevation and expected sea level rise) or defines a calculation to be performed. Once the start map has been created, the iteration operation can be done. 


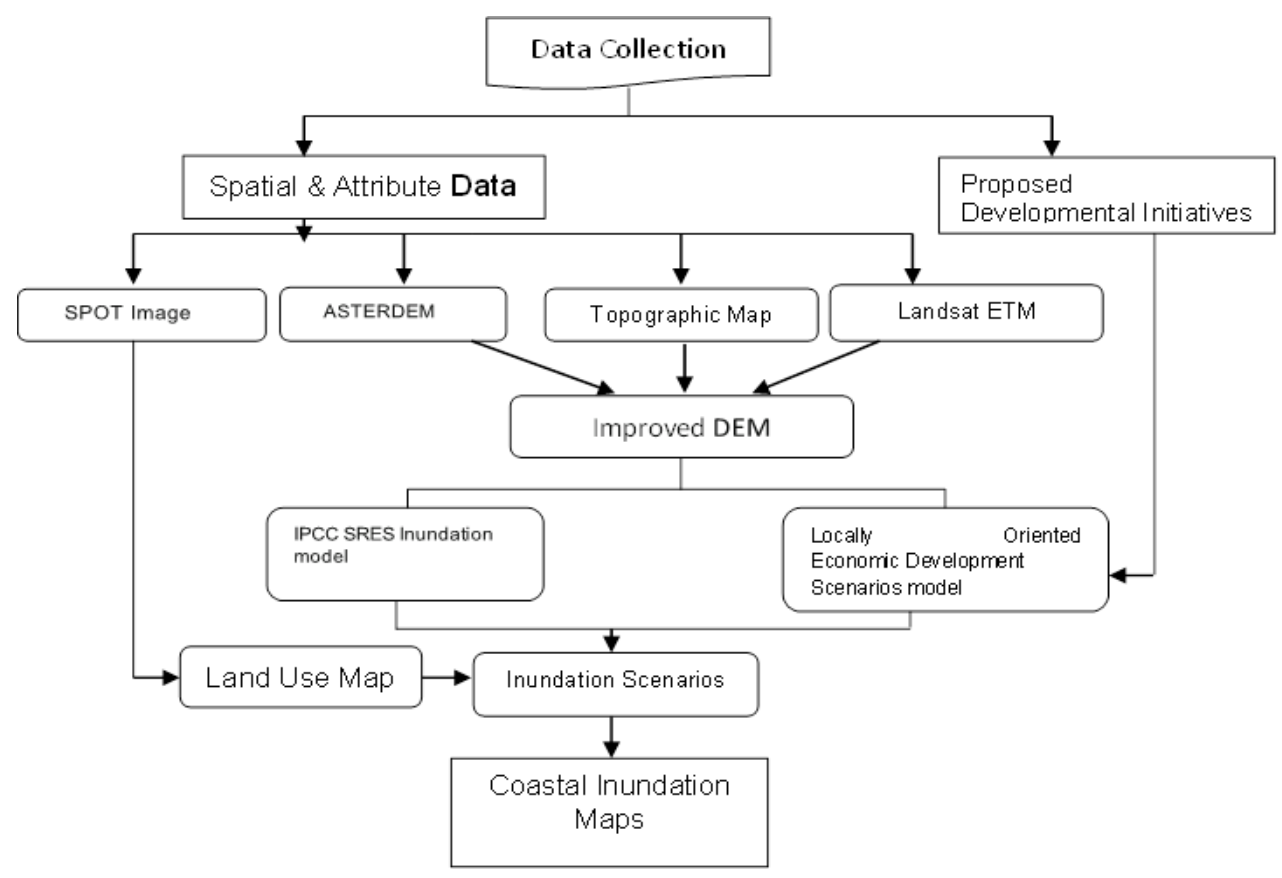

Fig 3: Methodological approach for the study of coastal inundation due to climate change

Table 1: Spatial Data characteristics

\begin{tabular}{|c|c|c|c|c|}
\hline $\mathbf{S} / \mathbf{N}$ & Data type & Scale/Resolution & Source & Date \\
\hline 1 & $\begin{array}{l}\text { High quality Digital } \\
\text { Elevation Model (ASTERDEM) }\end{array}$ & 30 meters & $\begin{array}{l}\text { NASA } \\
\text { asterweb.jpl.nasa.gov/gdem.asp }\end{array}$ & 2011 \\
\hline 2 & Sea level rise predictions (SRES) & Global & $\begin{array}{l}\text { IPCC } \\
\text { http://www.ipcc.ch/publications_and_data/publications_and_data_repor } \\
\text { ts.shtml }\end{array}$ & 2000 \\
\hline 3 & SPOT image & 10 meters & EADS ASTRIUM & 2008 \\
\hline 4 & $\begin{array}{l}\text { Landsat ETM } \\
\text { r191c056 }\end{array}$ & 30 meters & $\begin{array}{l}\text { GLCF (Department of Geography, University of Maryland) } \\
\text { http://www.landcover.org }\end{array}$ & $\begin{array}{l}2000 \text { and } \\
2006\end{array}$ \\
\hline 5 & $\begin{array}{l}\text { Topographic map } \\
\text { Badagri NE1, NW1 and NW2 }\end{array}$ & $1: 25,000$ & Federal Surveys Department & 1985 \\
\hline
\end{tabular}

It has however been noted that the IPCC scenarios do not encompass the full range of possible futures as emissions may change less than the scenarios imply, or they could change more (Karl etal 2009). The scenarios do not also project all the possible future environmental changes (IPCC- SRES, 2000). This study, consequently upon these observation considered other extreme scenarios resulting in local disturbances from unprecedented anthropogenic activities in the area to possible catastrophic tectonic sea level rise. Specifically, the impact of a sea level rise of 3 to 10 meters as a result of Locally Oriented Economic Development (LOED) of the study area was assessed.

Inundation Based on IPCC-SRES Scenarios: The output of the iteration process reveals that in the event of a 0.18 (B1 scenario), 0.59 (A1FI scenario) or 1 meter rise in sea level (excluding future rapid dynamical changes in ice flow) about 9.44 ha (table
3) of land will be inundated within this range of prediction. This is highly insignificant and the land use pattern will only be modified by local anthropogenic activities. In other words, the result shows that climate change and in particular, sea level rise will not have significant impact with respect to coastal inundation on the study area based on IPCCSRES projection. Even the A1F1 scenario impact is highly negligible. The anthropogenic changes in the area will results from local stressors. Also, the 9.44 ha expected to be inundated under the worse IPCCSRES prediction falls within the cultivated areas that are currently known to always been flooded during storm rainfalls.

\section{RESULTS AND DISCUSSIONS}

Land use: Table 2 shows the present land use distribution along the Badagry coastline and environment. The present status shows that built up area covered about $25.97 \%$ (1919.77 ha.) of the total 
area. This is followed by scattered cultivation with about $20.09 \%$. (1485.08 ha.). However, the bulk of the areas that are currently scattered cultivation, mining pits, mangrove swamp and wet land have been acquired for developmental purposes including the proposed Badagry Greenfield Port complex. It is expected that these developments will bring additional stress on the coastal biodiversity and might create a totally different morphological dynamics within the micro environment. These new local morphological dynamics may result in coastal accretion and erosion depending on the impacts on local wave and onshore current.

Table 2: The Land Use Land Cover

Classification Map of the area reveals that

\begin{tabular}{rlll}
\hline S/N & Luclass & $\begin{array}{c}\text { Area in } \\
\text { Hectare }\end{array}$ & $\begin{array}{l}\text { \% } \\
\text { Covered }\end{array}$ \\
\hline $\mathbf{1}$ & Built Up Area & 1919.77 & 25.97 \\
$\mathbf{2}$ & Grass Land & 522.64 & 7.07 \\
$\mathbf{3}$ & Mangrove Swamp & 967.26 & 13.08 \\
$\mathbf{4}$ & Mining Pit & 896.57 & 12.13 \\
$\mathbf{5}$ & Palm Plantation & 634.57 & 8.58 \\
$\mathbf{6}$ & Riparian Forest & 58.26 & 0.79 \\
$\mathbf{7}$ & Sand Beach & 92 & 1.24 \\
$\mathbf{8}$ & Scattered Cultivation & 1485.08 & 20.09 \\
$\mathbf{9}$ & Water Body & 214.4 & 2.90 \\
$\mathbf{1 0}$ & Wetland & 603.01 & 8.16 \\
& Total Area Covered & 7393.56 & 100.00 \\
& by Land use & & \\
\hline
\end{tabular}

However, and as noted earlier, the IPCC-SRES predictions are not totally encompassing as they are likely to be less or more than the predicted value. With the recent upsurge of development on the Lagos Badagry coast, especially with the creation of Eko Atlantic City and the proposed Badagry Greenfield Port, the future behavior and reaction of the Badagry coast to sea level rise may be difficult to decipher. To this end, it becomes imperative that other levels of sea rise predictions have to be considered to cover all possible future scenarios.
Inundation Based on Locally Oriented Economic Development Scenarios (LOEDS): Table 3 shows the statistics of area inundated from different sea level rise scenario. The iteration process for the marginally extreme $3 \mathrm{~m}$ sea level rise scenario revealed that 18.88 ha of land will be inundated (fig 4) with an average of $9,442.77 \mathrm{~m}^{3}$ volume of water. The expected inundation area for the $3 \mathrm{~m}$ sea level is about $0.26 \%$ of the total study area and is presently occupied by scattered cultivation land use type. Morphologically, it represents areas with the steepest depression.

Table 3: Sea Level Rise inundation area due to locally oriented economic development

\begin{tabular}{lcccl}
\hline $\begin{array}{l}\text { Sea level } \\
\text { Rise (m) }\end{array}$ & $\begin{array}{l}\text { No of } \\
\text { Pixel }\end{array}$ & $\begin{array}{l}\text { Area } \\
\text { (ha.) }\end{array}$ & $\begin{array}{l}\text { \% } \\
\text { from } \\
\text { total } \\
\text { area }\end{array}$ & $\begin{array}{l}\text { Scenario } \\
\text { Type }\end{array}$ \\
\hline $\mathbf{0 - 1}$ & 1 & 9.44 & 0.13 & Ipcc Sres \\
$\mathbf{2}$ & 2 & 18.88 & 0.26 & Loeds \\
$\mathbf{3}$ & 2 & 18.88 & 0.26 & Loeds \\
$\mathbf{4}$ & 69 & 654.38 & 8.85 & Loeds \\
$\mathbf{5}$ & 74 & 702.05 & 9.50 & Loeds \\
$\mathbf{6}$ & 159 & 1497.66 & 20.26 & Loeds \\
$\mathbf{7}$ & 173 & 1632.84 & 22.08 & Loeds \\
$\mathbf{8}$ & 190 & 1791.05 & 24.22 & Loeds \\
$\mathbf{9}$ & 204 & 1925.76 & 26.05 & Loeds \\
$\mathbf{1 0}$ & 543 & 5125.92 & 69.33 & Loeds \\
\hline
\end{tabular}

For the $5 \mathrm{~m}$ sea level rise (as shown in table 5), the iteration process revealed that about 702.05 ha occupying $9.50 \%$ of the study area will be inundated with $278,535,230.6 \mathrm{~m}^{3}$ volume of water. Specifically, the areas that will be inundated will start from the coast and extend landward and will include the large expanse of palm plantation, riparian forest, scattered cultivation, wetland, mangrove swamp and built up areas like Seme, Igbogele, Ogungbe, Kweme and Asakpo amongst others. Substantial parts of the expressway (Lagos-Badagry Expressway) which links Nigeria to other West Africa countries like 
Benin Republic, Togo and Ghana among others will also be inundated (figure 5).

For the $7 \mathrm{~m}$ sea level rise scenario (fig 6), the iteration process revealed that about 1632.84 ha of land (representing $22.08 \%$ of the study area) will be inundated with about $713,873,297.57 \mathrm{~m}^{3}$ volume of water. Thus, in addition to the areas that will be submerged in the event of the 5 meters sea level rise, the inundated areas in this case will extend to the Badagry creek and cover land use types like sand beach, palm plantation, wetland, mangrove swamp, grassland, scattered cultivation and some part of the Badagry creek. Settlements that will be inundated in addition to those already mentioned under $5 \mathrm{~m}$ sea level rise scenario will include: Akoko, Gbaji, Apa, Wesere, Ganyingbo and Igbogele ropoji amongst others. At this level of salt water intrusion, several other environmental problems, land degradation and aquatic biodiversity loss will be expected. This will have significant impacts on food security, water supply and other ecosystem services.

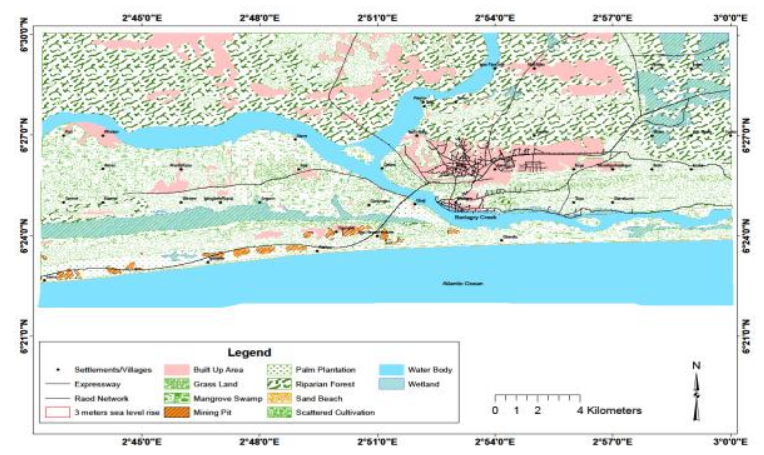

Fig 4: 3 meter marginal sea level rise due to locally oriented economic development

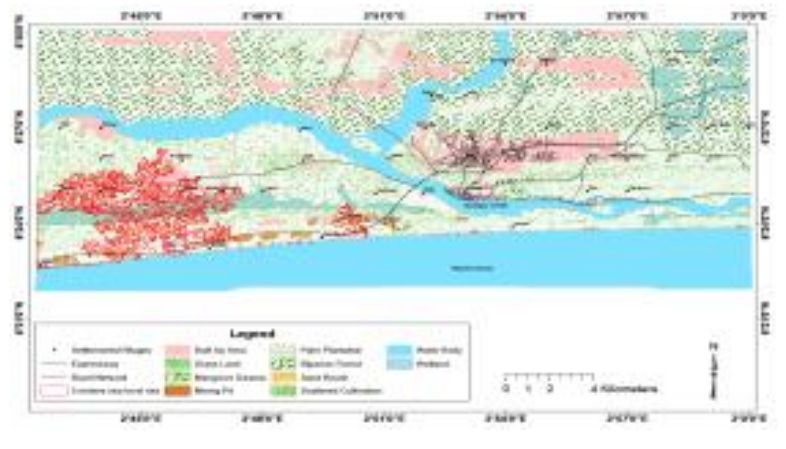

Fig 5: $5 \mathrm{~m}$ marginal sea level rise due to locally oriented
For the $9 \mathrm{~m}$ sea level rise scenario (fig 7), the iteration process revealed that 1925.76 ha (representing $26.05 \%$ of the study area) will be inundated with $1,187,076,866.18 \mathrm{~m}^{3}$ volume of water. The inundated areas in this case will have spread across the Badagry creek at the eastern part of the study area into communities like Topo, Akarakumo and some parts of Badagry town. The whole of the road network and all settlements from the border town up to the Yewa Bridge will be inundated with this level of sea rise. At the level, the Administrative Staff College of Nigeria (ASCON) in Topo will be under threat. The environmental problems identified in $7 \mathrm{~m}$ sea level rise will also apply. For 10 meters sea level rise (fig

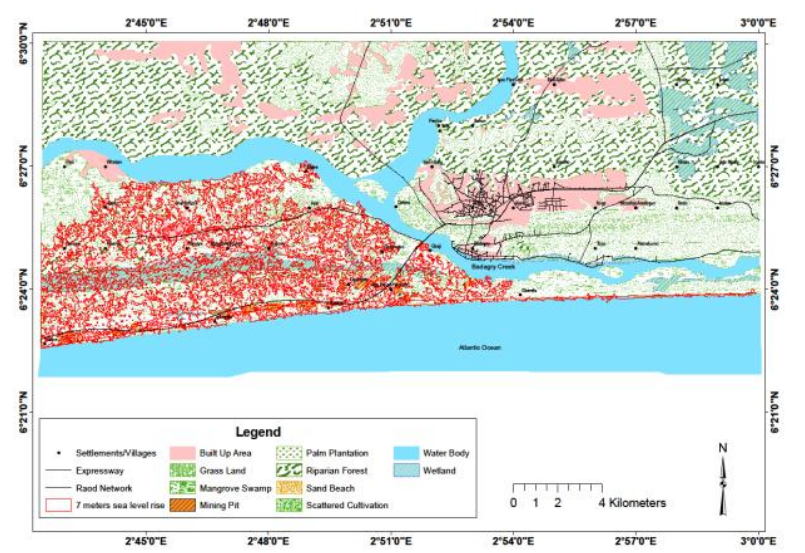

Fig 6: $7 \mathrm{~m}$ marginal sea level rise due to locally oriented economic development
8), the iteration process revealed that 5125.92 ha (representing $69.33 \%$ of the study area) will be inundated with about $1,540,453,591.23 \mathrm{~m}^{3}$ volume of water. The area that will be inundated in this case will be extended to the whole of Badagry town, parts of Ajara town and Doforo amongst others. The road network in the area will also be inundated and the fresh water of the Badagry creek will further be polluted with salt water. The creeks fresh water biological life will be totally altered through loss of several organisms and aquatic life. A new kind of aquatic species within the system will also emerge.

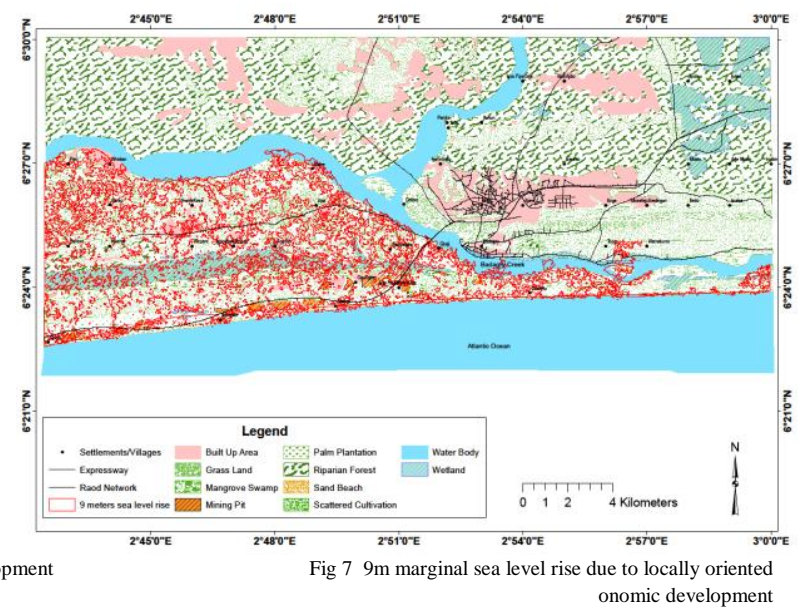




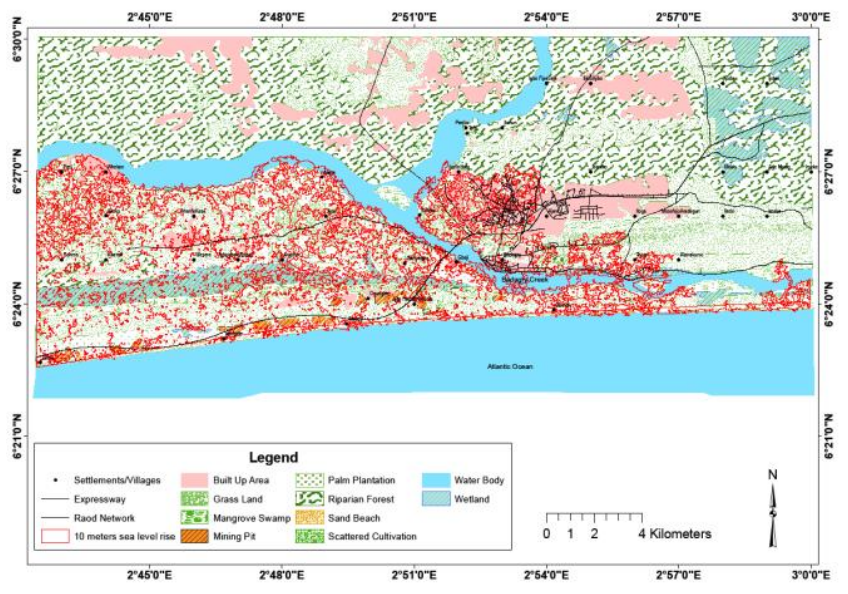

Fig 8: $10 \mathrm{~m}$ marginal sea level rise due to locally oriented economic development

Conclusion and Recommendation:This study reveals that the impact of anticipated temperature increase and sea level rise under the IPCC - SRES story lines will not have any significant impact on the inundation processes around the Badagry coastal area. However, inundation based on locally oriented economic development scenarios (LOEDS) shows that the current accretion process along the shoreline may be reversed and some level of erosion and shoreline retro-gradation should be expected if LOEDS scenario attain 4 meters and above. Total area expected to be inundated ranges between $8.85 \%$ at 4 meters to $69.33 \%$ at 10 meters. Since it is environmental catastrophism and anthropogenic activities of high magnitude that can bring about such unusual sea level rise within the study area, it is recommended that coastal protection infrastructures should be integrated in any major developmental activity.

\section{REFERENCES}

Adebayo, S.I. 1998 Climate change and global warming and high frequency of storm surges along the Atlantic Coast of Nigeria. Proceedings of Sustain Africa, 4: 6-8.

Adefolalu, D.O., Pam, J, L., Habbi, H. M. (2007) "Climate change and safety of air transportation - A Nigerian perspective". Proceedings of the International Conference on the impacts of extreme weather and climate on socio-economic development in Africa held at the Federal University of Technology, Akure, Nigeria, 11-15 Nov. 2007. pp. 1-15.

Adepelumi, A. A. (2008) Delineation of Saltwater intrusion into the freshwater aquifer of Lekki Peninsula, Lagos, Nigeria. The 3rd International
Conference on Water Resources and Arid Environments and the 1st Arab Water Forum.

Adepelumi, A. A. and Olorunfemi, M. O. (2000)

Engineering geological and geophysical investigation of the reclaimed Lekki Peninsula, Lagos southwest Nigeria. Bulletin of Engineering Geology and the Environment. Vol. 58, pp. 125-132.

Awosika, L. F., Osuntogun. N. C., Oyewo, E. O. and Awobamise, A. (2001) Development and Protection of the Coastal and Marine Environment in Sub Sahara Africa: Report of the Nigeria Integrated Problem Analysis.

Chindo, A., Nyelong, P.N. (2005) "Lake Chad: From Megalake to Minilake", Arid Wetland Bull. No. 6: 24 - 27.

Ikhile, C.I. (2007) "Impacts of climate variability and change on the hydrology and water resources of the Benin-Owena River Basin", $\mathrm{Ph} \mathrm{D}$ thesis submitted to the Department of Geography and Regional Planning, University of Benin, Benin City, Nigeria.

IPCC, (2000) In: Nakicenovic, N., Swart, R. (Eds.), Special report on emissions scenarios. Cambridge University Press, Cambridge.

IPCC-SRES (2000): IPCC Special ReportEmission Scenarios. A special Report of IPCC Working Group III-Summary for Policy Makers.

Intergovernmental Panel on Climate (IPCC), 2007 Climate change 2007: Synthesis report. 
Summary for policy makers", available at: http://www.ipcc-wg1-ucar.edu/wg1/wg1report.htm, (accessed 26 October 2009).

Jagtap, S. (2007) Managing vulnerability to extreme weather and climate events: Implications for agriculture and food security in Africa. Proceedings of the International Conference on Climate Change and Economic Sustainability held at Nnamdi Azikiwe University, Enugu, Nigeria. 12-14 June 2007.

Karl, T.R., Melillo, J.M. and Peterson, T.C., (2009) Global Climate Change Impacts in the United States. Cambridge University Press.

Longe, E. O., Malomo, S., Olorunniwo, M. A. (1987) Hydrogeology of Lagos metropolis. J. Afr. Earth Sci., 6(3):163-174.

Marfai, M. A., King, L. (2008) Potential vulnerability implications of coastal inundation due to sea level rise for the coastal zone of Semarang city, Indonesia. Environ Geo 54:1235-1245. doi:10.1007/s00254-007-0906-4

Mshelia, A. D. (2005). "Adaptation strategies to climate change", J. Energy Environ., 18 (3): 74 81.

Nicholls, R.J., Hanson, S., Herweijer, C., Patmore, N., Hallegatte, S., Corfee-Morlot, J., Cha^teau, J., Muir-Wood, R. (2007) Ranking port cities with high exposure and vulnerability to climate extremes-exposure estimates. OECD environmental working paper no. 1, Organisation for Economic Co-operation and Development (OECD), Paris.

Nigerian Environmental Study/action Team (NEST) (2003) Climate change in Nigeria. A communication guide for reporters and educators. NEST, Ibadan.

National Population Commission, (2007) National Gazetteer for 2006 Population Census.
Nwafor, J.C. (2007) Global climate change: The driver of multiple causes of flood intensity in Sub-Saharan Africa. Paper presented at the International Conference on Climate Change and Economic Sustainability held at Nnamdi Azikiwe University, Enugu, Nigeria. 12- 14 June 2007.

Odjugo, P.A.O (2005) "An analysis of rainfall pattern in Nigeria", Global J. Environ. Sci., 4(2): 139-145.

Odjugo, P.A.O, Ikhuoria, A.I. (2003) The impact of climate change and anthropogenic factors on desertification in the semi-arid region of Nigeria. Global Journal of Environmental Science, 2(2): 118-126.

Pelling, M. and Blackburn, S. (2012) Megacities and the Coast: Risk, Resilience and Transformation, Land -Ocean Interactions in the Coastal Zone INPRINT, issue 3 www.loicz.org.

Simms, A. (2006) Up in smoke? Latin America and the Caribbean: the threat from climate change to the environment and human development. 3rd report, Working Group on Climate Change and Development. London, UK, New Economics Foundation.

UN, (2004): Guidelines for reducing flood losses, UN inter-agency secretariat forthe international strategy for disaster reduction, Geneva. 83p

Ward, P.J., Marfai, M. A., Yulianto, F., Hizbaron, D. R. and Aerts, J. C. J. H. (2011) Coastal inundation and damage exposure estimation. Nat Hazards 56:899-916 DOI $10.1007 / \mathrm{s} 11069-010-9599-1$ 